Farum

Sociológico

\section{Forum Sociológico}

Série II

31 | 2017

Transition to work of graduates in Southern Europe:

Crisis and new challenges

\title{
Italian graduates' employability in times of economic crisis : overview, problems and possible solutions
}

A inserção profissional de diplomados italianos em tempos de crise económica: uma visão global, os problemas e as possíveis soluções

Michele Rostan and Adriana Stan

\section{OpenEdition}

\section{Journals}

\section{Electronic version}

URL: https://journals.openedition.org/sociologico/1818

DOI: 10.4000/sociologico.1818

ISSN: 2182-7427

\section{Publisher}

CICS.NOVA - Centro Interdisciplinar de Ciências Sociais da Universidade Nova de Lisboa

\section{Electronic reference}

Michele Rostan and Adriana Stan, "Italian graduates' employability in times of economic crisis : overview, problems and possible solutions ", Forum Sociológico [Online], 31 | 2017, Online since 31 December 2017, connection on 29 March 2022. URL: http://journals.openedition.org/sociologico/1818 ; DOI: https://doi.org/10.4000/sociologico.1818 


\title{
ITALIAN GRADUATES' EMPLOYABILITY IN TIMES OF ECONOMIC CRISIS: OVERVIEW, PROBLEMS AND POSSIBLE SOLUTIONS A INSERÇÃO PROFISSIONAL DE DIPLOMADOS ITALIANOS EM TEMPOS DE CRISE ECONÓMICA: UMA VISÃO GLOBAL, OS PROBLEMAS E AS POSSÍVEIS SOLUÇÕES
}

\author{
Michele Rostan \\ Università degli Studi di Pavia, Dipartimento di Scienze Politiche e Sociali, CIRSIS - Centre for Study and Research on \\ Higher Education Systems \\ Adriana Stan \\ Università degli Studi di Pavia, Dipartimento di Scienze Politiche e Sociali, CIRSIS - Centre for Study and Research on \\ Higher Education Systems
}

\begin{abstract}
Albstract
Relying on various sources of data, the article aims to prove an overview on Italian graduates' employment and labour market participation in times of economic crisis. It provides a short description of Italy's higher education, economy and labour market, and an analysis of graduate employment, especially focusing on fresh graduates. Three possible views on the Italian case are also suggested, and some recent policy initiatives fostering graduate employability both at the national and the local levels are illustrated. In order to offer a better understanding of the topic, the Italian situation is occasionally compared to the situation of Germany, the leading economy in Europe.
\end{abstract}

Keywords: graduate employability, graduate employment and work, graduate labour market, Italy

\begin{abstract}
Resumo
Com base em diversas fontes de dados, este artigo pretende contribuir para uma visão geral sobre o emprego e a participação no mercado de trabalho dos graduados italianos em tempos de crise económica. O texto inclui uma breve descrição do ensino superior italiano, da economia e do mercado de trabalho, bem como uma análise do emprego dos graduados com especial enfoque nos que o são há menos tempo. São sugeridas três perspetivas possíveis sobre o caso italiano, assim como se ilustram algumas iniciativas políticas recentes que procuram promover a inserção profissional dos graduados, tanto a nível nacional como a nível local. Por forma a permitir uma compreensão mais aprofundada do tema, a situação italiana é ocasionalmente comparada à situação da Alemanha, país economicamente líder na Europa.
\end{abstract}

Palavras-chaves: inserção professional de diplomados, emprego e trabalho de diplomados, mercado de trabalho de diplomados, Itália

\section{Introduction: graduate employability in Italy}

In Italy, the concern for graduate employability - broadly understood as referring to the relationship between higher education studies and subsequent graduate employment (Teichler, 2011;
Tomlinson, 2012) - has varied over the decades. It has been higher in times of faster expansion of higher education and during economic crises. This has happened at least twice. Firstly, when Italian higher education moved from an elite to a mass system in the late ' 60 s and early ' 70 s, and the international 
economic crisis of the '70s hit the Italian economy. Secondly, after the expansion of the system following the implementation of the Bologna Process in the 2000s, and the period of global economic downturn of the past decade (Ballarino, 2015; Moscati and Pugliese, 1996).

In these two periods both public debate and scholarly investigation focused on similar issues: the economic system's poor capacity to create and maintain adequate jobs for graduates, a supply of graduates exceeding the demand of highly - qualified labour, the length of time needed to move from study to work, prolonged or repeated graduate unemployment, possible graduate over - education, the shift from standard employment to various forms of non-standard contracts, and marked differences in graduate employment and work according to gender, region and field of study (Ballarino and Bratti, 2009; De Francesco and Trivellato, 1978; Ghirardini and Pellinghelli, 2000; Maestripieri and Ranci, 2016; Moscati and Rostan, 2000; Santoro and Pisati, 1996; Trombetti and Stanchi, 2006).

From a comparative perspective, before the introduction of the European framework of study programmes prompted by the Bologna Process, Italian graduates' employment and work conditions stood out among other European countries in terms of fewer work experiences during study, including traineeships and internships, more self-employment, a higher proportion of graduates working in small and medium - size firms, longer periods of job searching, the higher importance of personal connections when searching for a job, less participation in the international labour market, a higher proportion of graduates experiencing a fragmented or troubled early career, lower wages, lower perceived career perspectives, a rather positive - but lower than in other countries - assessment of the degree of consistency between levels of education and jobs (Allen and van der Velden, 2011; Rostan, 2006; Schomburg and Teichler, 2006; Teichler, 2007), whereas after the implementation of the Bologna Process evidence and outcomes are a mix of both positive and negative elements (Cammelli et al., 2011; Fondazione G. Agnelli, 2012; Rostan, 2008; Schomburg, 2011).

Different, albeit not necessarily alternative, views relying on various theories and approaches have been proposed to account for the characteristics of Italian graduates' employment and work conditions (Ballarino, 2007; 2015).

The first view looks at the structure of the Italian production system. According to this view, the poor employment and working conditions of Italian graduates are influenced by the features of the national economy. Although Italy was, and still is, like Germany, one of the most industrialised countries in Europe, its production system is charac- terised by the prevalence of small and medium - size firms, mature technologies, family ownership, and less educated entrepreneurs. Also, the economy's capacity for innovation is poorer than in other European countries; both the private service sector and the public one are less developed than in other advanced economies and the proportion of persons employed in managerial, professional, technical and associated professional occupations is lower than in a number of other European countries. Briefly, the Italian economy seems to lack the characteristics, in terms of company size, specialisation, technology and innovation, which favour a high level of employment of graduates (Reyneri, 2005; Rostan, 2006; Teichler, 2011). Moreover, these characteristics make the economy less able to valorise and reward qualified human capital triggering a "vicious circle" linking lower returns on human capital, lower investment in it, a lower endowment of it, lower innovation capacity, and a lower level of economic growth, again resulting in a lower capacity to reward qualified human capital (Cipollone and Sestito, 2010; Visco, 2009). This "vicious circle" may also explain the Italian paradox of displaying, at the same time, lower levels of participation in higher education, resulting in a lower endowment of human capital, and lower returns on university degrees, which in turn result in smaller differences between university graduates' and secondary school graduates' wages compared to other European countries (Bernardi and Ballarino, 2014).

The second view considers the expansion of higher education, especially the structure of the Italian higher education system. According to this view, the expansion of higher education in Italy is not strongly associated with the demand for highly - qualified human capital, and is better explained by other factors: an increase in family incomes, the pressure for less privileged social groups to access higher education, the pressure by the middle class to maintain an educational advantage over other social groups, the action of the state and the academy (Ballarino, 2011; Moscati, 2006). The expansion of the system would have produced consequences such as "credential inflation", "intellectual unemployment" and over-supply of graduates, especially in some fields, thus negatively affecting the employment and working conditions of graduates (Barbagli, 1974; Barone, 2012; Collins, 2011). Regardless of the causes, in Italy the expansion of the higher education system has not been accompanied by its diversification like in other countries. In almost all other European countries, a non-university sector offering applied and vocational programmes has been established alongside the university sector, or vocational programmes and/or units offering technical education have been created within universities. These programmes and institutions accommodated 
a large proportion of the growing demand for higher or tertiary education, strengthened the relationships between the education system and firms, and provided both the production system and welfare services with a qualified labour force, all of which resulted in better employment prospects for graduates. Similar measures have not been implemented in Italy, or have been introduced to a very limited extent. Consequently, the traditional disconnection between universities and the economy has lasted longer, and the opportunity to provide professional profiles with tertiary education well suited to the Italian production system was lost (AA.VV., 1973; Ballarino, 2015; Kyvik, 2004; Moscati, 1986; TreeLLLe, 2008).

While the two first views variously rely on human capital theory, market approaches or institutional and neo-institutional theories and approaches, the third view refers to network theories (Barbieri, 1997; Granovetter, 1974; Rosenbaum et al., 1990). According to this view, graduates' employment outcomes are strictly connected to their participation in social networks fostering the circulation and exchange of relevant information on graduates' and jobs' characteristics. These networks may consist of relationships between universities and firms, established and maintained both by individual faculty and job placement and career services as well as by the relationships among peers (students, graduates and colleagues). Therefore, this view stresses the importance of factors such as individual and corporate actors' behaviours, channels of communication and trust for a successful transition from higher education to work and to graduates' careers.

The concern for graduate employability has not only prompted public debate and scholarly reflection but has also fostered an increasing interest in data collection on graduate employment and work. Thus, in the past decades the employment outcomes of Italian graduates and some characteristics of their employment and work have been continuously monitored.

ISTAT - the national agency for statistics started a programme of surveys on graduates' employment outcomes in 1989, interviewing a large samples of graduates approximately three years after graduation (ISTAT, 1990). The ninth edition of the survey was carried out in 2015 by interviewing a sample of students graduating in 2011 (ISTAT, 2016).

In 1998, AlmaLaurea - a newly established inter-university consortium - launched a programme to monitor the employment outcomes of graduates from member universities. This consisted in annual interviews of all graduates one, three and five years after graduation (AlmaLaurea, 2000). As membership expanded, AlmaLaurea has been able to collect relevant information on a growing proportion of Italian graduates. In 2016, 620,000 graduates from 71 universities - accounting for $90 \%$ of the students graduating each year - were interviewed (AlmaLaurea, 2017).

Besides national inquiries, Italy has also participated in the two major international graduate studies undertaken in Europe in the past decades, namely the CHEERS study - "Careers after Higher Education: A European Research Study" - (Rostan, 2006; Schomburg and Teichler, 2006; Teichler, 2007), and the REFLEX study - "The Flexible Professional in the Knowledge Society" - (Allen and van der Velden, 2011).

Relying on various sources of data, this article aims to provide an overview of Italian graduates' employment and labour market participation in times of economic crisis. First, we provide a short description of the Italian economy and labour market. Second, we analyse graduate employment, especially focusing on fresh graduates. Third we provide some evidence supporting the three main views on Italian graduates' employment and work conditions we have illustrated, especially looking at recent policy initiatives fostering graduate employability both at the national and the local levels. The following paragraphs are based on data drawn - directly or indirectly - from four sources: the National Statistics Agency (ISTAT), the Ministry of Education (MIUR), the National Student Register (ANS) and AlmaLaurea (AL). These sources are complemented with other national or local ones. In order to offer a better understanding of the topic, the Italian situation is occasionally compared to the German one - that is, with the situation of the leading economy in Europe - as well as to other European countries.

\section{Italy's economic outlook and the general labour market}

During the past decade, the Italian economy was hit by the recession twice. As shown by the GDP growth rate (Fig. 1), the country suffered a first downturn in 2009 and a second one in 2012. Thereafter, recovery has been very slow. Although slightly different, recent forecasts on GDP growth are positive. It is expected that the Italian economy will grow in 2017 by $0.5 \%$ (Confindustria, September 2016), 0.8\% (Consensus Economics, September 2016) or $1.0 \%$ (Government, September 2016).

The recession has had a strong impact on the labour market. As data on employment rates show (Tab. 1), the economy's capacity to provide jobs worsened and many jobs were lost. Between 2008 and 2013 the employment rate decreased by 3 points and one million jobs disappeared (ISTAT, 2016). Meanwhile, unemployment increased. Between 2008 and 2014, the unemployment rate rose by 6 points (Tab. 1). 
Only since 2014 has the situation improved. Employment is slowly increasing and unemployment is slowly decreasing.

To better appreciate the Italian situation in times of crisis, let us briefly compare it with the situation of the leading economy in Europe, Germany. The Italian and the German economies were both hit by the economic downturn in 2009, more or less to the same extent. Yet, Germany had better economic performance in the previous years and reacted to the economic crisis more effectively than Italy (Fig. 1).

There are at least two differences between Italy and Germany, which are worth mentioning. First, before the economic crisis, Germany was already more capable of creating jobs than Italy, and while Italy's employment rate worsened slightly after 2008, Germany's rate improved slightly after that year (Tab. 2).

Second, while before the crisis unemployment was lower in Italy than it was in Germany after 2009 the two economies followed divergent paths, with Germany's unemployment figures decreasing slightly while Italy's consistently increased (Fig. 2).

\section{Graduate employment in a period of recession}

Who suffered most from the economic crisis? Young people did. In order to assess the labour market conditions of Italian youth, we will focus our attention on two groups of people. First, young people aged 20 to 24 years who hold an upper secondary or post-secondary (but non-tertiary) education diploma. Second, people aged 25 to 29 years holding a tertiary education degree. As we can see from Fig. 3, the employment rates of young people holding a high school diploma decreased by more than 10 points from 2008 onwards and their employment situation has not recovered.

The impact on tertiary education graduates has been similar. Their employment rate lost more than 10 points as well, although it grew in 2015. To have a better understanding of young graduates'

Table $1 \triangleright$ Total employment and unemployment rates in Italy

\begin{tabular}{|c|c|c|c|c|c|c|c|c|c|c|c|}
\hline Year & 2005 & 2006 & 2007 & 2008 & 2009 & 2010 & 2011 & 2012 & 2013 & 2014 & 2015 \\
\hline Total employment rate (\%) & 57,6 & 58,3 & 58,6 & 58,6 & 57,4 & 56,8 & 56,8 & 56,6 & 55,5 & 55,7 & 56,3 \\
\hline Total unemployment rate (\%) & 7,7 & 6,8 & 6,1 & 6,7 & 7,7 & 8,4 & 8,4 & 10,7 & 12,1 & 12,7 & 11,9 \\
\hline
\end{tabular}

Source: Eurostat Employment rates by sex, age and educational attainment level (\%) [lfsa ergaed]. Retrieved from http://appsso.eurostat. ec.europa.eu/nui/show.do?dataset=Ifsa_ergaed\&lang=en, Eurostat. Retrieved from http://ec.europa.eu/eurostat/tgm/table.do?tab $=$ table\&init $=1 \&$ plugin $=1 \&$ language $=$ en\&pcode $=$ tsdec 450

Figure $1 \triangleright$ GDP growth rate in Italy and Germany

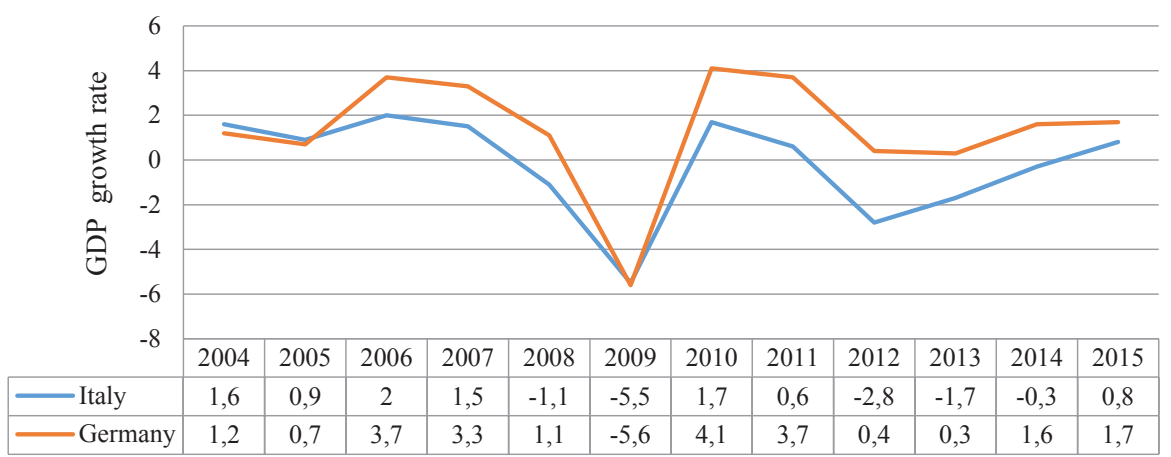

Source: Eurostat. Retrieved from http://ec.europa.eu/eurostat/tgm/table.do?tab=table\&init=1\&plugin $=1 \&$ language $=$ en $\&$ pcode $=$ tec00 115

Table $2 \triangleright$ Total employment and unemployment rates in Italy

\begin{tabular}{l|ccccccccccc}
\hline \multicolumn{1}{c}{ Year } & $\mathbf{2 0 0 5}$ & $\mathbf{2 0 0 6}$ & $\mathbf{2 0 0 7}$ & $\mathbf{2 0 0 8}$ & $\mathbf{2 0 0 9}$ & $\mathbf{2 0 1 0}$ & $\mathbf{2 0 1 1}$ & $\mathbf{2 0 1 2}$ & $\mathbf{2 0 1 3}$ & $\mathbf{2 0 1 4}$ \\
\hline Italy & 57,6 & 58,3 & 58,6 & 58,6 & 57,4 & 56,8 & 56,8 & 56,6 & 55,5 & 55,7 \\
Germany & 65,5 & 67,2 & 69 & 70,1 & 70,3 & 71,3 & 72,7 & 73 & 73,5 & 73,8 \\
\hline
\end{tabular}

Source: Eurostat Employment rates by sex, age and educational attainment level (\%) [Ifsa_ergaed]. Retrieved from http://appsso.eurostat. ec.europa.eu/nui/show.do?dataset=Ifsa_ergaed\&lang=en 
Figure $2 \triangleright$ Unemployment rates in Italy and Germany

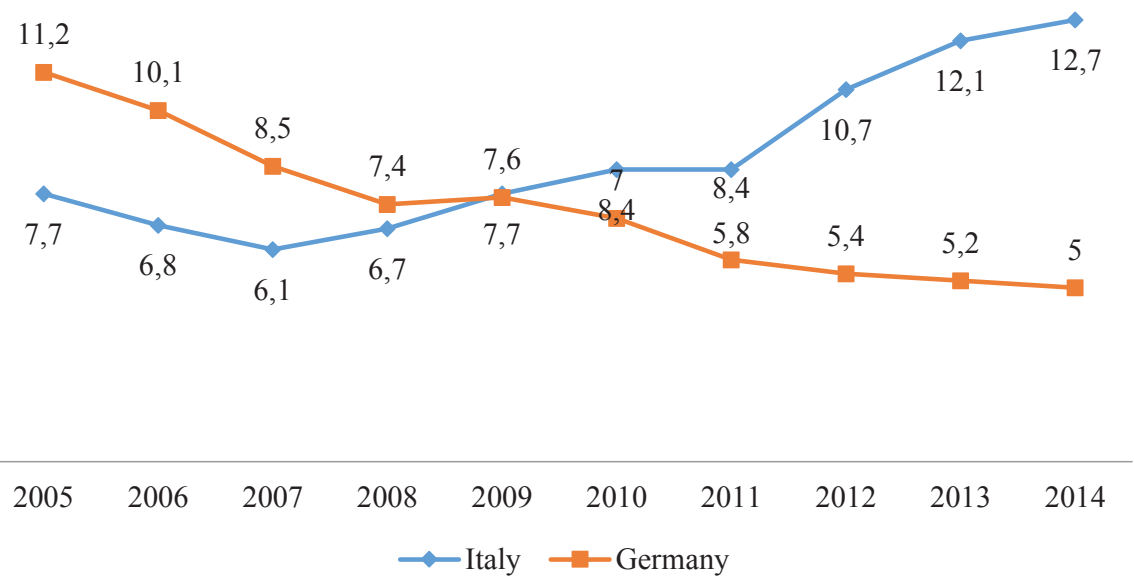

Source: Eurostat. Retrieved from http://ec.europa.eu/eurostat/tgm/table.do?tab=table\&init=1\&plugin=1\&language=en\&pcode=tsdec450

employment conditions, it is useful to compare their employment rates with the general ones (Fig. 4).

As we can see, in 2008 the graduates' employment rate outperformed the general rate $(61.3 \%$ vs $58.6 \%$ ), while in 2013 the opposite was true, and in 2015 it slowly recovered but was still quite far from the general rate. In sum, we can say that the economic recession affected young graduates less than their younger brothers and sisters holding only a high school diploma, but more than the labour

Figure $3 \triangleright$ Employment in Italy by age and educational attainment

\begin{tabular}{llllllllllll}
60,7 & 55,9 & 60,5 & 59,6 & 61,3 & 57,7 & 53,9 & 55,7 & 54,7 & 50,2 & 47,9 & 49,3 \\
\hline 39,5 & 38,2 & 39,3 & 38,8 & 38,8 & 35,2 & 33,5 & 32,5 & 31,4 & 27,8 & 27,4 & 27,3 \\
\hline
\end{tabular}

$\begin{array}{llllllllllll}2004 & 2005 & 2006 & 2007 & 2008 & 2009 & 2010 & 2011 & 2012 & 2013 & 2014 & 2015\end{array}$

_ From 20 to 24 years - Upper secondary and post-secondary non-tertiary education From 25 to 29 years - Tertiary education (levels 5-8)

Source: Eurostat Employment rates by sex, age and educational attainment level (\%) [lfsa_ergaed]. Retrieved from http://appsso.eurostat. ec.europa.eu/nui/show.do?dataset=Ifsa_ergaed\&lang=en

Figure $4 \triangleright$ Graduates' and general employment rates: a comparison

\begin{tabular}{lllllllllllll}
60,7 & 55,9 & 60,5 & 59,6 & 61,3 & 57,7 & 53,9 & 55,7 & 54,7 & 50,2 & 47,9 & 49,3 \\
\hline 39,5 & 38,2 & 39,3 & 38,8 & 38,8 & 35,2 & 33,5 & 32,5 & 31,4 & 27,8 & 27,4 & 27,3 \\
\hline
\end{tabular}

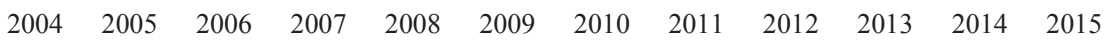

— From 20 to 24 years - Upper secondary and post-secondary non-tertiary education

- From 25 to 29 years - Tertiary education (levels 5-8)

Source: Eurostat Employment rates by sex, age and educational attainment level (\%) [Ifsa_ergaed]. Retrieved from http://appsso.eurostat. ec.europa.eu/nui/show.do?dataset=Ifsa_ergaed\&lang=en 
force as a whole. Let us finally add - although relying on national data ${ }^{1}$ - that according to the respective national trends, the employment condition of young German university graduates has improved since 2009, while this has not happened with young Italian university graduates.

Graduates' employment and educational conditions one year after graduation

In order to outline the employment situation of Italian graduates, let us focus on three aspects: a) graduates' employment conditions one year after graduation; b) employed graduates' type of contract; c) employed graduates' wages.

We consider first and second-cycle graduates (excluding long first-cycle ones) and we compare the graduates' situation in 2008, when the financial crisis started to produce its effects, with their situation at two other points in time, 2012 and 2015. We do not use Eurostat data but rely on national data collected by AlmaLaurea.

In Table 4, we focus on two pieces of evidence. We consider employed graduates, people saying they have a paid job, excluding training activities such as internships, traineeships, and practicums, compared to their colleagues who are neither employed nor searching for a job (mostly because they are still in education or training) and to those who are not employed but are searching for a job. The percentage of employed first-cycle graduates dropped between 2008 and 2012, and again between 2012 and 2015, while the percentage of employed second-cycle graduates remained practically unchanged in the two periods under consideration.

Secondly, among first-cycle graduates there are no large gender differences. The percentage of employed graduates by gender is very similar and both sexes were affected in the same measure by the economic crisis. Things are somewhat different for second-cycle graduates. Among men, the percentage of employed graduates is higher than among women, and men seem to be affected by the economic crisis slightly more than women.

At the time of the interview, employed graduates were asked to state their employment situation at the time of graduation. Three different conditions were reported: a) graduates who are employed at the time of the interview, were employed at the time of graduation and have the same job that they initiated before graduation; b) graduates who are employed, were employed but have changed their job; c) graduates who were not employed and started to work after graduation.

In Table 5 we focus our attention on graduates who started to work after graduation, as their condition is likely more dependent on the business cycle and can be considered an indicator of the economy's capacity to create jobs for fresh graduates.

The percentage of first-cycle graduates starting to work after graduation was quite low in 2008 $(40 \%)$ and remained so in 2012, while in 2015 it increased consistently ( +6.7 points). The picture was different for second-cycle graduates. In fact, they were affected more strongly in the first phase of the crisis. In $2008,59.2 \%$ of those who were

Table $3 \triangleright$ Graduates' employment in Italy and Germany

\begin{tabular}{|c|c|c|c|c|c|c|}
\hline \multirow{2}{*}{ Employed graduates (\%) } & \multicolumn{3}{|c|}{ First cycle } & \multicolumn{3}{|c|}{ Second cycle } \\
\hline & 2008 & 2012 & $\Delta \%$ pt. & 2008 & 2012 & $\Delta \% \mathrm{pt}$. \\
\hline Italy & 42 & 40.6 & -1.4 & 53.7 & 53.8 & 0.1 \\
\hline Germany & 37 & 42 & 5 & 61 & 74 & 13 \\
\hline
\end{tabular}

Source: KOAB and AlmaLaurea.

Table $4 \nabla$ Italian graduates' employment and study conditions one year after graduation

\begin{tabular}{|c|c|c|c|c|c|c|c|c|c|c|}
\hline \multirow{2}{*}{ Employment condition (\%) } & \multicolumn{5}{|c|}{ First cycle } & \multicolumn{5}{|c|}{ Second cycle } \\
\hline & 2008 & 2012 & $\Delta$ 2008-2012 & 2015 & $\Delta$ 2012-2015 & 2008 & 2012 & $\Delta 2008-2012$ & 2015 & $\Delta 2012-2015$ \\
\hline Employed & 42 & 40.6 & -1.4 & 38.4 & -2.2 & 53.7 & 53.8 & 0.1 & 53.7 & -0.1 \\
\hline Neither employed nor searching & 36.5 & 32.4 & -4.1 & 38 & 5.6 & 18.9 & 13.6 & -5.3 & 17.1 & 3.5 \\
\hline Not employed and searching & 21.5 & 27 & 5.5 & 23.6 & -3.4 & 27.4 & 32.6 & 5.2 & 29.2 & -3.4 \\
\hline Total & 100 & 100 & & 100 & & 100 & 100 & & 100 & \\
\hline \multicolumn{11}{|l|}{ Employed by gender } \\
\hline Males & 41 & 40 & -1 & 37.5 & -2.5 & 60.9 & 58.1 & -2.8 & 58 & -0.1 \\
\hline Females & 42.6 & 40.9 & -1.7 & 39 & -1.9 & 52.3 & 50.8 & -1.5 & 50.6 & -0.2 \\
\hline
\end{tabular}

Source: AlmaLaurea. 
Table $5 \triangleright$ Italians employed one year after graduation who were not employed and started to work after graduation

\begin{tabular}{|c|c|c|c|c|c|c|c|c|c|c|c|c|}
\hline & \multicolumn{6}{|c|}{ First cycle } & \multicolumn{6}{|c|}{ Second cycle } \\
\hline & 2008 & 2012 & $\Delta$ & $2008-2012$ & 2015 & $\Delta$ 2012-2015 & 2008 & 2012 & $\Delta$ & $2008-2012$ & 2015 & $\Delta 2008-2012$ \\
\hline $\begin{array}{l}\text { Graduates who were not employed } \\
\text { and started to work after graduation }\end{array}$ & 40.2 & 39.4 & & -0.8 & 46.1 & 6.7 & 59.2 & 49.9 & & -9.3 & 53.7 & 3,8 \\
\hline
\end{tabular}

Source: AlmaLaurea.

employed started to work after graduation, while in 2012 this percentage was $49.9 \%$ ( -9.3 points). In the second phase, after 2012, things were better and the percentage of those starting to work after graduation increased ( +3.8 points).

AlmaLaurea also provides data on graduate employment rates one year after graduation relying on the definition used by ISTAT in its Labour Force Surveys which include among employed graduates also those who are involved in paid training activities. The calculation includes only first-cycle graduates who are not enrolled in other study programmes, as well as all second-cycle graduates. The resulting picture is slightly different from the above-mentioned one, but the perceived impact of the business cycle is similar. Among first-cycle graduates the employment rate dropped from $77.4 \%$ in 2008 to $65.8 \%$ in $2012(-11.6$ points), slightly rising slightly to $68.2 \%$ in 2015 (+2.4 points). Among second-cycle graduates the employment rate fell from $75.2 \%$ in 2008 to $69.8 \%(-5.4$ points), rising slightly to $70.8 \%$ in 2015 (+1 point).

Type of contract

Graduate employment can also be analysed according to the type of contract graduates have.
We can distinguish two main working conditions. On the one hand, we have what may be called "typical" or "standard" employment. On the other hand, we have what we may call "atypical" or "non-standard" employment. The first category brings together self-employed graduates and those having a permanent contract. The second category includes graduates having various kinds of temporary employment. While full details can be found in Table 6, here we can say that, one year after graduation:

- Atypical employment is more frequent both among first and second-cycle graduates, than typical employment;

- Among first-cycle graduates, permanent jobs and self-employment decreased a little between 2008 and 2012, climbing back to pre-crisis levels after 2012;

- Again, among first-cycle graduates the figures for atypical employment remained practically unchanged in the years under consideration;

- Among second-cycle graduates atypical positions decreased over the whole period under consideration, while typical positions increased slightly.

Table $6 \triangleright$ Type of contract

\begin{tabular}{|c|c|c|c|c|c|c|c|c|c|c|}
\hline \multirow{2}{*}{ Type of contract (\%) } & \multicolumn{5}{|c|}{ First cycle } & \multicolumn{5}{|c|}{ Second cycle } \\
\hline & 2008 & 2012 & $\Delta 2008-2012$ & 2015 & $\Delta 2012-2015$ & 2008 & 2012 & $\Delta$ 2008-2012 & 2015 & $\Delta 2012-2015$ \\
\hline Self-employment & 7.7 & 11.3 & 3.6 & 12.6 & 1.3 & 6.7 & 9.2 & 2.5 & 9.2 & 0 \\
\hline Permanent contract & 28.2 & 22.2 & -6 & 23.1 & 0.9 & 24.7 & 24.7 & 0 & 26.9 & 2.2 \\
\hline $\begin{array}{l}\text { Total "typical" or "standard" } \\
\text { employment }\end{array}$ & 36 & 33.5 & -2.5 & 35.7 & 2.2 & 31.3 & 33.9 & 2.6 & 36.1 & 2.2 \\
\hline Traineeship/apprenticeship & 8 & 7.3 & -0.7 & 7.4 & 0.1 & 14.5 & 13.7 & -0.8 & 14.4 & 0.7 \\
\hline Fixed-term contract & 21.1 & 26.4 & 5.3 & 30.6 & 4.2 & 20.9 & 23.8 & 2.9 & 28.4 & 4.6 \\
\hline Consultancy & 17.1 & 7.3 & -9.8 & 5.2 & -2.1 & 23.6 & 11.4 & -12.2 & 7.2 & -4.2 \\
\hline Other atypical contract & 6.2 & 10.1 & 3.9 & 8.6 & -1.5 & 3.9 & 7.7 & 3.8 & 6.1 & -1.6 \\
\hline $\begin{array}{l}\text { Total "atypical" or "non-standard" } \\
\text { employment }\end{array}$ & 44.4 & 43.8 & -0.6 & 44.4 & 0.6 & 48.3 & 42.9 & -5.4 & 41.7 & -1.2 \\
\hline Without contract & 11.3 & 14.9 & 3.6 & 11.4 & -3.5 & 5.7 & 9.3 & 3.6 & 5.8 & -3.5 \\
\hline Part-time employment & 40.8 & 51.7 & 10.9 & 47.8 & -3.9 & 23.8 & 32.1 & 8.3 & 27.6 & -4.5 \\
\hline
\end{tabular}

Source: AlmaLaurea. 
Wages

Finally, we look at wages. As shown in Table 7, average monthly (net) wages decreased during the first phase of the crisis, recovering after 2012 for both first and second-cycle graduates. It can also be seen that second-cycle graduates benefit from a rather small but increasing wage premium compared to first-cycle graduates.

In sum, the recession has had a strong impact on the Italian labour market, affecting young graduates less than high school graduates but more than the labour force as a whole. Although with some slight differences, the impact of the business cycle following the world financial crisis in terms of the employment conditions and wages of both first and second-cycle fresh graduates is evident, but it is less so in terms of their type of contract.

Before the financial crisis, Germany was better off ithan Italy $\mathrm{n}$ terms of employment but not in terms of unemployment. Subsequently, though, Germany's advantage over Italy increased in both respects. In particular, the employment conditions of young German university graduates have improved, while this has not happened with young Italian university graduates.

What we know suggests that the difficulties that young Italian people experience in the labour market are a long-lasting structural feature of the Italian economy, and the economic crisis has worsened an already unsatisfactory situation. In Italy, compared to Germany, higher education graduates' employability has been and remains poor. As mentioned above, there are at least three views that may possibly explain this shortcoming: a demand-side view, looking at the structure of the production system; a supply-side view, considering the structure of the higher education system; and a third view taking into account links and missing links between demand and supply. In the sections that follow, we will provide some evidence supporting each view, as well as turning our attention to some policy measures aiming to enhance graduate employability.

\section{The demand-side view: the structure of the production system}

Italy is still the second most industrialised country in Europe, after Germany (OECD, 2013; 2015a). Unlike Germany, however, its production system displays several traits, which hinder graduates' employability. In Italy, $0.6 \%$ of industrial firms have more than 49 employees, while in Germany these firms represent 3\% of their total number, that is more than five times as much. In Italy, large enterprises employ $32.6 \%$ of employees, while in Germany they employ $58 \%$ of employees (Tab. 8).

Firms operating in high-tech sectors and highly-educated employees in technology and knowledge-intensive sectors sharply differentiate the two economies (Tab. 9).

High-tech sectors account for $2.8 \%$ of the total in Italy and $4.6 \%$ in Germany (industry + service sector). Technology and knowledge-intensive sectors employ $33.4 \%$ of highly-educated workers (i.e. holding a higher education/tertiary degree) in Italy and $46.4 \%$ in Germany. It is worth noting that data on Italy include mostly university graduates while those on Germany include both university graduates and $\mathrm{FH}$ graduates. Business enterprise expenditure on R\&D as a percentage of GDP is higher in Germany than in Italy: $1.9 \%$ vs $0.71 \%$ in 2013. Although family-controlled businesses are similarly frequent in Italy and in Germany, family involvement in management is higher in Italy than in Germany (Bugamelli et al., 2012).

Table $7 \triangleright$ Average monthly net income (in €)

\begin{tabular}{|c|c|c|c|c|c|c|c|c|c|}
\hline \multicolumn{5}{|c|}{ First cycle } & \multicolumn{5}{|c|}{ Second cycle } \\
\hline 2008 & 2012 & $\Delta$ 2008-2012 & 2015 & $\Delta$ 2012-2015 & 2008 & 2012 & $\Delta$ 2008-2012 & 2015 & $\Delta 2012-2015$ \\
\hline 933 & 837 & -96 & 931 & 94 & 1053 & 1013 & -40 & 1116 & 103 \\
\hline
\end{tabular}

Source: AlmaLaurea.

Table $8 \triangleright$ Firms and employees by size in Italy and Germany (2013)

\begin{tabular}{l|cc|cc}
\hline \multicolumn{1}{c|}{ Firms' size } & \multicolumn{2}{c|}{ Italy } & \multicolumn{2}{c}{ Germany } \\
& \% Employees & \% Firms & \% Employees & \% Firms \\
\hline Small (1-9 employees) & 46.3 & 94.8 & 18.9 & 82.2 \\
Medium (10-49) & 21.1 & 4.6 & 23.1 & 14.7 \\
Large (50 or more) & 32.6 & 0.6 & 58 & 3 \\
\hline
\end{tabular}

Source: OECD, Dataset: SDBS Structural Business Statistics (ISIC Rev. 4). Retrieved from http://stats.oecd.org/Index.aspx?DataSetCode=SDBS_BDI 
Table $9 \triangleright$ High-technology sectors (2013)

\begin{tabular}{|c|c|c|c|c|}
\hline & \multicolumn{2}{|c|}{ Italy } & \multicolumn{2}{|c|}{ Germany } \\
\hline & Sectors \% & Employees \% & Sectors \% & Employees \% \\
\hline $\begin{array}{l}\text { High-technology sectors (high-technology manufacturing } \\
\text { and knowledge-intensive high-technology services) }\end{array}$ & 2.8 & 33.4 & 4.6 & 46.4 \\
\hline \multicolumn{5}{|l|}{ Of which: } \\
\hline Medium high-technology manufacturing & 10.1 & 11.8 & 14.3 & 30.1 \\
\hline High-technology manufacturing & 1.4 & 24.7 & 4.0 & 38.4 \\
\hline Medium low-technology manufacturing & 34.9 & 5.1 & 36.6 & 16.5 \\
\hline Low-technology manufacturing & 53.6 & 6.4 & 45.0 & 17.2 \\
\hline Total knowledge-intensive services & 3.6 & 40.5 & 5.5 & 43.2 \\
\hline
\end{tabular}

Source: Eurostat: Enterprises in high-tech sectors by NACE Rev.2 activity [htec_eco_ent2]; Eurostat: Employment in technology and knowledge-intensive sectors at the national level, by level of education (from 2008 onwards, NACE Rev. 2) [htec_emp_nisced2].

Briefly, considering the different graduates' employment outcomes in the two countries and the differences between the two economies in terms of size of enterprises, sector specialisation, utilisation of qualified labour, expenditure in R\&D activities, and management, the structure of the German production system seems to be more favourable to the employability of higher education graduates than the Italian one.

The supply-side view: the structure of the higher education system

The Italian university system consists of 96 institutions enrolling some $1,670,000$ students in the 2015/2016 academic year (ANS, 2017; ANVUR, 2016). Most students - $90 \%$ - attend courses at the 66 state universities and $43 \%$ of students are enrolled in the 12 largest institutions, which are state universities.

Outside the university sector, there are 140 institutions providing higher education in art and music, enrolling 86,000 students. There are also other institutions providing tertiary education: theological seminaries, advanced schools for "linguistic mediators" (interpreters and translators), higher technical institutes (Istituti Tecnici Superiori - ITS) and private institutions providing tertiary vocational education in many fields. While ITSs - supplemented by other private institutions - do offer non-university tertiary education, these programmes and institutions cannot be considered a well-integrated and well-developed non-university higher education or tertiary education sector.

The present situation is rooted in the past. Historically, Italy's higher education has been developed under strong state monopoly. Moreover, it has been largely dominated by one type of institution, namely the university, and there has been less room for diversification between higher education institutions.
In the early 1980s doctoral degrees were introduced, and in the early 1990s new short-study programmes providing so-called "diplomi universitari" were also established, affording some vertical diversification to higher education programmes.

More importantly, though, in the 2000s the new European framework of qualifications was introduced following the Reform of 1999. A new framework with three main degrees replaced the old one. The three degrees are: the "laurea", a first-level degree corresponding to a bachelor's degree, the "laurea specialistica" (renamed as "laurea magistrale" by the 2004 Reform), a second-level degree corresponding to a master's degree, and the "dottorato di ricerca", i.e. a PhD, at the third level. As a consequence, the Reform has given a steeper vertical structure to the Italian higher education system. Yet, very little horizontal or functional diversification has been provided. Italy has never experienced a binary system in the past, nor is this the case nowadays.

Participation in the Italian university system greatly widened during the past half-century. In Martin Trow's terms (1974; 2006), Italy's higher education moved from an elite system to a mass system from the mid-1960s to the mid-1970s, reaching 30 students enrolled for the first time in higher education out of 100 young people aged 19 in 1975. Between the mid-1970s and the end of the 1980s, participation slowed down, and it was only after 1988 that the movement towards universal access restarted. In 2001 there were 53 students enrolled for the first time out of 100 young people aged 19. In the following years the enrolment rate remained well above $50 \%{ }^{2}$. It is widely acknowledged that the 1999 Reform played a crucial role in widening participation in higher education, producing one of the most important changes in the Italian university system.

Consequently, when analysing the system's input (i.e. students enrolled for the first time per 
year) and its output (i.e. graduates per year) it seems appropriate to focus on more recent years.

According to the National Student Register, the number of students enrolling for the first time in higher education grew in the years following the implementation of the university reform, reaching the maximum of 337,000 students in $2003 / 2004$. After that, enrolments fell to the minimum of 265,500 students in 2013/2014 (-20\%) and rising slightly thereafter to 275,000 in $2015 / 2016(+2 \%)$. In this period, more than half of the students enrolled per year (55\%) were female. ANVUR's data analysis shows that this ten-year-long falling trend was due to several factors: a) in 2006, the end of the incentives for the enrolment of mature students which accompanied the first phase of the implementation of the reform and resulte in a considerable increase in mature people enrolling in higher education; b) a decrease in the enrolment rate of young secondary school graduates (aged 20 or less) starting at the end of the 2010s; c) the rise within the youth population in the incidence of young immigrants aged 18-20, whose enrolment rate in higher education is sharply below that of their native counterparts. Focusing only on young Italian students after 2007, ANVUR states that "considering the impact of the economic crisis on family income, the decrease in the enrolment rate might be ascribed to the economic difficulties of the poorer families in supporting their children's university studies, considering as well the persistent inadequacy of State support in this field. This might explain the more significant fall among young people living in the South and Island, as well as students coming from technical secondary education, where there is a higher incidence of young people from families of lower social and cultural status" (ANVUR, 2016: 89; our translation).

Following the implementation of the 1999 university Reform, the composition of Italian university system's output has changed. The number of students completing their studies holding the old degree has progressively decreased, while the number of those gaining the new degrees has increased. In the first years after the Reform the number of students gaining the new bachelor's degree also increased because students from the old system were given the chance to transfer to the new one while keeping their credits and quickly completing the new degree. If we look at the total number of degrees earned annually, data from the Ministry of Education show an increase in their number from 172,000 in 2001 to the maximum of 301,000 in $2006(+75 \%)$, flowed by a decrease to the minimum of 289,000 in 2010 ( $-4 \%)$ and an increase to the new maximum of 305,000 in $2014(+5.5 \%)$. Deducting from the total the number of second-cycle degrees, i.e. master's degrees, it is possible to determine the number of graduates earning either a new first-cycle degree, i.e. a bachelor's, or a long first-cycle degree, i.e. degrees from the EU-regulated programmes' degrees such as medicine, or an old first-cycle degree, per year. The number of graduates increased from $172,000$ in 2001 to 216,000 in 2014 ( $+25.6 \%)$. The latter number can reasonably be compared to the number of students graduating in the last year before the implementation of the Reform, that is, in 2000 . That year, there were $-152,000$ graduates from Italian universities. All in all, we can say that the number of graduates per year has increased in the past 15 years $(+42 \%)$.

Although the number of graduates has increased, nevertheless international comparisons show that the proportion of people holding a tertiary education degree in the Italian population is still unsatisfactory. According to EUROSTAT, among young Italian people aged 25-34 the proportion of those holding a tertiary education degree (ISCED, 2012, levels 5 to 8 ) has increased from $10.5 \%$ in 2000 to $24.2 \%$ in 2014 . Unfortunately, this proportion is quite far below the European average, $37.3 \%$ in 2014 (EU 27), as well as from EU policy targets for 2020 (ANVUR, 2016: 180).

The international comparison based on OECD data (OECD, 2015b: 41) shows that the proportion of young Italian people aged 25-34 holding a master's degree (ISCED, 2011, level 7) is similar to that of other countries such as Germany and France ( $15 \%$ vs $13 \%$ and $14 \%$ ), while the proportion of young people holding a bachelor's degree (ISCED, 2011 , level 6) is lower ( $9 \%$ vs $14 \%$ and $12 \%$ ) and nobody holds a short-cycle tertiary education degree (ISCED, 2011, level 5) while in France 18\% do. In short, it is very likely that Italy's shortfall is due to the absence or underdevelopment of a nonuniversity higher education sector and other forms of tertiary education.

All in all, it can be argued that in Italy participation in higher education has widened and the number of graduates has increased. The Italian university system reached the highest point in its expansion, with $1,824,000$ enrolled students, just before the international economic crisis broke out.

\section{The third view: links and missing links between higher education and the world of work}

While the two previous explanations focus either on the demand side or the supply side of the labour market, the third view looks at the relationship between demand and supply, and to the links connecting higher education and the economic sector. According to this view, problems in the employability of graduates arise from factors such as weak or malfunctioning communication channels linking universities and firms, the poor quality 
of information on jobs and candidates exchanged between higher education and the economic sector, the effectiveness of the tools connecting demand and supply, and the quantity and quality of the collaboration between universities and firms. In periods of economic crisis, one would expect some of the tools used to connect higher education and the world of work to be strengthened in order to face a more critical situation. This does not seem to be the case. Take for instance one of the more widespread tools employed to shorten the distance between higher education and the economic sector, namely traineeships during study. Considering this indicator is especially important in Italy, for two reasons. First, before the implementation of the Bologna Process very few students participated in traineeships and internships during study. In this respect the university reform of the early 2000s fostered a great change in Italy's higher education system. Second, a multivariate analysis carried out by AlmaLaurea shows that, other things being equal, participating in traineeships and internships during the course of study increases the probability of being employed one year after graduation (AlmaLaurea, 2017). Thus, it is likely that traineeships and internships - allowing both employers and students to collect valuable information - are a good way of improving the connection between - higher education and the economy.

Table 10 shows the percentage of undergraduate and graduate students participating in traineeships during their studies (students attending long first-cycle programmes, such as medicine, are not included in the data). In times of crisis, the proportion of students with no traineeship experience grows, albeit slightly. But the second series of data is even more important. Students may participate in traineeships in three different ways: a) working students have the opportunity to gain traineeship credits on-the-job; b) students can participate in traineeship activities within their university; c) students can participate in traineeships outside their university, whether in the private, public or notfor-profit sectors. As you can see, the proportion of students participating in traineeships outside their university dropped in 2012, although there was a subsquent recovery. The decrease for second cycle students is significant.

Therefore, we can conclude that the economic crisis has had a further negative effect by impairing a tool that is useful to link demand and supply of the graduate labour force. Traineerships and internships, though, are not the only way to strengthen the links between higher education and the economy. As we will see in the next section, other measures have also been proposed to enhance graduate employability.

\section{Recent policies for graduate employability}

National policies for youth employability

There are few nataional public policies directly aimed at enhancing graduate employability. On the other hand, there are national public policies aimed at enhancing youth employability in general. At the moment, the most important one is called "Garanzia Giovani", which is Italian for "Youth Guarantee". Youth Guarantee has been especially aimed at young people who are neither in education nor in employment or training (NEETs). Italy is the top-ranking country in the European Union regarding NEET rates. In 2015, the percentage of young people aged 15-24 who were neither in education nor in employment or training, was $21.4 \%$ (Eurostat). If we consider young people aged $15-29$, the percentage was $24.8 \%$ (ISTAT). Briefly, in our country there are over 2 million NEETs. Consequently, policies targeting the NEET issue are crucial (http://www.garanziagiovani.gov.it).

What is more interesting for us, however, is that graduates are also participating in the Youth Guarantee programme. Unfortunately, central authorities do not provide up-to-date information on young people participating in the programme, broken down by educational attainment. But regional authorities do have these data. For instance, it is possible to look at the Province of Novara, in Piedmont (Northwestern Italy), which is a rich province with a local economy based on a mix of agriculture, industry and services (Balduzzi, 2016). In this Province, 3,621 young people were registered in the Youth Guarantee

Table $10 \triangleright$ Students' participation in traineerships during study

\begin{tabular}{|c|c|c|c|c|c|c|c|c|c|c|}
\hline & \multicolumn{5}{|c|}{ First cycle } & \multicolumn{5}{|c|}{ Second cycle } \\
\hline & 2008 & 2012 & $\Delta 2008-2012$ & 2015 & $\Delta 2012-2015$ & 2008 & 2012 & $\Delta$ 2008-2012 & 2015 & $\Delta$ 2012-2015 \\
\hline Students participating in traineerships & 60.4 & 59.8 & -0.6 & 58.7 & -1.1 & 55 & 56.1 & 1.1 & 56.6 & 0.5 \\
\hline \multicolumn{11}{|l|}{ Students participating in traineerships ... } \\
\hline ... within their university & 12.5 & 11.6 & -0.9 & 10.3 & -1.3 & 12.2 & 12.1 & -0.1 & 11.6 & -0.5 \\
\hline ... outside their university & 47.5 & 39.1 & -8.4 & 39.5 & 0.4 & 42.4 & 30.6 & -11.8 & 32.8 & 2.2 \\
\hline Students with no traineership experience & 38.9 & 39.8 & 0.9 & 41.3 & 1.5 & 44.4 & 43.4 & -1 & 43.4 & 0 \\
\hline
\end{tabular}

Source: AlmaLaurea. 
programme in January 2015. It was possible to find out the educational attainment of 2,873 of them: $52 \%$ held an upper secondary degree, 35\% held a lower degree and $13 \%$ held a tertiary education degree. These percentages are similar to those of the entire population of NEETs at the national level before the launch of the Youth Guarantee initiative (ISTAT, 2014).

If the Youth Guarantee programme is an example of national policy aimed directly at enhancing youth employability (and employment) which also happens to include graduates, there are examples of national policies that, are directly addressed to university students and which might have an indirect impact on their future employment. One of these policies is the national programme aimed at increasing the number of students (and graduates) in scientific and technological disciplines. The policy consists of two main measures:

- A national programme fostering better links between upper secondary schools and universities, aimed at orienting high school students towards scientific or technological university study courses ("Piano nazionale lauree scientifiche" / PLS);

- National incentives for students enrolling in scientific and technological university study programmes (chemistry, physics, mathematics, statistics, geology, ICT, industrial engineering, construction, and, more recently, biology and biotechnology) ("Fondo per il sostegno dei giovani e per favorire la mobilità degli studenti" and "Decreto Ministeriale 29 dicembre 2014 n. 976").

These are examples of predominantly "topdown" policies promoted by the European Union and the national government, and implemented with the cooperation of other public and private actors, including universities. But there is another set of policies, which is at least as important as the others, and which consists predominantly of "bottom-up" initiatives promoted by the universities themselves.

Universities building new tools: the case of AlmaLaurea

The most important initiative of this type aimed at enhancing graduate employability is the creation of a consortium among universities, called AlmaLaurea. The University of Bologna promoted AlmaLaurea in 1994. At the beginning, a dozen universities participated in the consortium. Nowadays, AlmaLaurea has 74 members accounting for $90 \%$ of Italian graduates, and the Ministry of Education and Universities supports its activities.

The core of AlmaLaurea's activity consists of a national repository of graduates' CVs. At present, the repository stores 2,350,000 CVs. CVs are initiated and maintained by students and graduates at a local level, and are available to employers on a national portal. Employers can publish both traineership and job offers nationally or locally through universities' placement websites, while students and graduates can search for traineerships or jobs. Employers can also select CVs among those available and address personal job offers to graduates. The AlmaLaurea portal and its local webpages have also become a very important working tool for university career and job placement services, as it gives universities the opportunity to establish and maintain relations with firms and other employers, to monitor the working destinations of their graduates, and to monitor traineership activities, both during study and after graduation. In short, in the past two decades the consortium has made a contribution to the creation of a nationwide graduate labour market, enhancing communication between universities, students, graduates and employers.

AlmaLaurea's core activity has been complemented with another important initiative, the national inquiry on graduate employment. As already mentioned, every year, graduates are interviewed one, three and five years after graduation. In this way, a remarkable amount of information on Italian graduates' work, employment and career is provided to universities, policy makers and the general public, including the graduates themselves, students and their families. Of course, as we have shown, scholars and researchers may use these data as well.

The offer of new university vocational programmes

A second example of a mixed approach to national policies fostering graduate employability focuses on universities. It has been proposed that universities should offer first-cycle "vocational" programmes. Such programmes would consist of a combination of formal education, laboratories and practical activities, and on-the-job training. These programmes would be organised by so-called "Scuole universitarie professionali" that is university vocational schools, similar to the French "Institutes Universitaires de Technologie". The governing bodies of these schools would consist of representatives of the academy, the private sector and the public sector. The new policy is advocated by a coalition including the Rectors' Conference (CRUI), the Ministry of Education and Universities, professional bodies (i.e. regulated professions), especially of the technical professions, and employers' associations, but - as far as we know - it is opposed by other relevant actors. As a result, although the new programmes are promoted by a Decree of the Ministry of Educa- 
tion (n. 987/2016, art. 8) their start in the academic year $2017 / 2018$ is still uncertain. The proposal aims to address several problems:

- To retrieve the experience of the short programmes - the so-called "Diplomi univeristari" -introduced in the 1990s and dismissed in the 2000s following the implementation of the Reform introducing the European framework of degrees; these programmes accounted for less than $10 \%$ of Italian graduates, were quite successful in some technical fields and were abandoned without any evaluation of their functioning and results;

- To answer some of the criticism against the implementation of the European framework of degrees based on the two-tiered system composed of a three-year first cycle and a two-year second cycle;

- To prepare mid-level technicians who according to some estimates - are required by firms and professions;

- To provide an alternative path to students who are at risk of dropping out - or are actually dropping out - from more demanding programmes, especially in engineering.

Briefly, the establishment - or re-establishment - of first-cycle vocational programmes would move the Italian higher education system towards a more diversified structure, making it more similar to other European higher education systems, with the aim of increasing the number of graduates and enhancing their employability.

Local initiatives for graduate employment: the LM+ programme at the University of Pavia

Finally, we would like to look at local initiatives fostering graduate employability. Of course, there are many, but we have chosen the LM+ programme at the University of Pavia because - to our knowledge - it is the only initiative of this type within Italian higher education.

The initiative aims to enhance the professional value of university education and training. Unlike the national initiative promoting vocational first-cycle courses, though, the LM+ programme refers to the second-cycle of higher education that is to masters' courses. In short, it aims to prepare highly-qualified professionals.

As mentioned above, second-cycle programmes provide a degree known as "laurea magistrale" (LM). Regular LM programmes last two years and are organised into four semesters. The LM+ initiative adds an extra semester to the normal structure of LM programmes, the "plus" in its name. Thus, the LM+ programme consists of five semesters. Two of them are dedicated to internships or assignments outside the university, mainly within a company. Students may be involved in a single working experience lasting one year (two terms) or in two separated periods lasting one term each. Participating students receive a monthly reimbursement of a minimum of $500 €$ and foreign experiences are also allowed. A specific project is assigned to each student, and two tutors supervise each student participating in the programme: one from the academic side and one and from the business side. Not all students can participate in the programme. The number of students who are admitted each year depends on the number of companies involved. At the end of the first year, students apply for the "plus" programme and are selected by the governing body of the masters' course on the basis of their grades and credits, and on the assessment of a joint steering committee including representatives of both the university and the employers. The pilot programme included five LM courses (Advanced Biotechnologies, Chemistry, Electronic Engineering, International Business and Entrepreneurship, and Philosophy), and more than 40 companies have already joined the LM+ programme.

Although the $\mathrm{LM}+$ programme is a single initiative, it has some important features:

- It promotes the participation of second-cycle students in external working experiences, trying to contrast the unsatisfactory situation created by the economic crisis which is documented by the data we have shown (Tab. 10);

- It offers both students and employers the opportunity to get to know each other and to check the quality of future graduates (prospective workers) as well as jobs;

- It fosters collaboration between the university and external actors, including but not limited to companies; LM+ involves a small number of selected students, but the cooperation of external actors within the programme may produce positive effects for a larger number of students and faculty in terms of regular traineerships, job placement and joint research;

- It involves study programmes from different disciplines, sciences and technology but also social sciences and humanities;

- It provides organisational innovation combining existing academic and labour regulations in a new way and adapting them to new goals, such as providing students with longer and more qualifying working experience during study, which can be adopted and replicated by other institutions.

Briefly, the LM+ programme provides a small but important contribution to the enhancement of graduate employability. 


\section{Conclusions}

The economic crisis starting in 2007-2008 has had a strong impact on the Italian labour market, especially affecting young people. The economic recession affected young graduates less than their younger brothers and sisters holding only a high school diploma, but more so than the labour force as a whole. Evidence provided on graduate employment in Italy brings us to at least two conclusions. On the one hand, graduates' employment appears to be immediately exposed to the effects of economic trends. The employment rate of young people aged 25-29 holding a tertiary degree - that is mainly a university degree worsened after 2008 but recovered after 2014. Although to a different extent, the percentage of both first-cycle and second-cycle graduates employed one year after graduation who were not employed at the time of graduation and started to work afterwards, decreased in the 20082012 period while increasing in the 2012-2015 period. Wages decreased during the first phase of the crisis, recovering after 2012 both for first and second-cycle graduates.

On the other hand, data also suggest that the economic crisis has worsened or left unchanged an already unsatisfactory situation. While the percentage of second-cycle graduates employed one year after graduation remained the same in the two periods under consideration, the percentage of first-cycle graduates in the same conditions decreased in both periods. The starting points for the two groups of graduates were different, however. Already in 2008, most first-cycle graduates were not employed one year after graduation because they either continue to study, were searching for a job or they were neither studying nor job-searching. Contrary to the aims of the 1999 university Reform - which intended to increase the proportion of young people entering the labour market with a first-cycle degree - and in the context of a country where the proportion of young people holding a bachelor's degree was, and still is, lower than in other European countries, the recession aggravated an already serious state of affairs.

Furthermore, while - as far as job quality is concerned - the situation of second-cycle graduates one year after graduation improved in the two periods under consideration because the percentage of people having an atypical contract decreased, nothing changed for first-cycle graduates. But, more importantly, in both cases the percentage of graduates working with an atypical contract largely outstripped that of graduates with a typical contract, regardless of the period taken into consideration. Therefore, both the recession and the subsequent timid recovery have left unchanged what appears to be a rather permanent feature of Italy's graduate labour market.
Searching for an explanation of the rather permanent employment and labour market conditions of Italian graduates, it seems appropriate to bring together different factors. The comparison with Germany shows that very likely, one of these factors lies in the structure of the Italian production system, especially its poor capacity to create qualified jobs for both first-cycle and second-cycle graduates. A possible second factor, though, refers to the structure of Italy's tertiary education, which is dominated by universities. Here, international comparisons point to the lack of a more diversified offer of post-secondary or tertiary education based on non-university programmes or differently organised university programmes. Finally, a third set of factors concerns the poor communication and the weak links between higher education and the economy.

Most of the policy initiatives we have illustrated - whether national or local, top-down or bottom-up, specifically addressed to young graduates or just including them among other young people - aim to transform higher education and/or strengthen its relationship with the economy. Many provide valuable - or at least promising - solutions to graduates' employment and labour market problems. Their success, however, will depend not only on their own effectiveness but also on their connection to other policy measures regarding research, innovation, and the transformation of industry and of the public sector.

\section{Notas}

1 Data for Italy are collected by the national inquiry on graduate employment by the AlmaLaurea consortium, while data for Germany are collected by KOAB - Kooperationsprojekt Absolventenstudien by INCHER-International Centre for Higher Education Research of the University of Kassel.

2 The calculation of the enrolment rate is not an easy exercise because of the existence of various sources of data (the National Statistics Agency, the Ministry of Education, the National Register of Students), interrupted time series, and differences in data due to administrative procedures. Regarding these issues, please refer to Rostan, 2011: 12-17, and ANVUR, 2016: 72-83.

\section{References}

AA.VV. (1973), Scuola e mercato del lavoro, Bologna, Il Mulino.

ALLEN, J. and R. van der Velden (eds.) (2011), The Flexible Professional in the Knowledge Society. New Challenges for Higher Education, Dordrecht, Springer.

ALMALAUREA (2000), Condizione occupazionale dei laureati 1997 ad un anno dalla laurea, Bologna, AlmaLaurea.

ALMALAUREA (2017), XIX Indagine condizione occupazionale dei laureati (Rapporto 2017), Bologna, AlmaLaurea (See also the summary in English: 
ALMALAUREA, (2017), Report on the Profile and Occupational Status of Graduates (Report 2017), Bologna, AlmaLaurea. Retrieved from http://www. almalaurea.it/sites/almalaurea.it/files/docs/universita/occupazione/occupazione15/abstract_almalaurea_reports_2017_en.pdf).

ANS (Anagrafe Nazionale degli Studenti) (2017), Archivio amministrativo degli iscritti al sistema universitario italiano, Roma, MIUR. Retrieved from http:// anagrafe.miur.it/index.php

ANVUR (Agenzia Nazionale di Valutazione del Sistema Universitario e della Ricerca) (2016), Rapporto biennale sullo stato del sistema universitario e della ricerca 2016, Roma, ANVUR.

BALDUZZI, G. (2016), Progetto CivicNeet - Prima analisi dei dati di Agenzia Piemonte Lavoro, Internal Report, Pavia, CIRSIS.

BALLARINO, G. (2007), "Sistemi formativi e mercato del lavoro", in M. Regini (ed.), La sociologia economica contemporanea, Roma-Bari, Laterza, pp. 231-257.

BALLARINO, G. (2011), "Le politiche per I'università", in U. Ascoli (ed.), Il welfare in Italia, Bologna, Il Mulino, pp. 197-223.

BALLARINO, G. (2015), "Gli esiti occupazionali dei laureati", in P. Trivellato and M. Triventi (eds.), L'istruzione superiore: caratteristiche, funzionamento e risultati, Roma, Carocci, pp. 213-245.

BALLARINO, G. and M. Bratti (2009), "Field of Study and University Graduates' Early Employment Outcomes in Italy during 1995-2004", LABOUR, 23(3), pp. 421-457.

BARBAGLI, M. (1974), Disoccupazione intellettuale e sistema scolastico in Italia (1859-1973), Bologna, Il Mulino.

BARBIERI, P. (1997), "Non c'è rete senza nodi. Il ruolo del capitale sociale nel mercato del lavoro", Stato e mercato, 49, pp. 67-109.

BARONE, C. (2012), "Contro l'espansione dell'istruzione (e per la sua ridistribuzione). Il caso della riforma universitaria del 3+2", Scuola Democratica, 4, pp. 54-75.

BERNARDI, F. e G. Ballarino (2014), "Participation, Equality of Opportunities and Returns to Tertiary Education in Contemporary Europe", European Societies, 16(3), pp. 422-442.

BUGAMELLI, M.; L. Cannari, et al. (2012), "Il gap innovativo del sistema produttivo italiano: radici e possibili rimedi", Questioni di Economia e Finanza (Occasional Papers), (121).

CAMMELLI, A.; G. Antonelli; A. Di Francia; G. Gasperoni and M. Sgarzi (2011), "Mixed Outcomes of the Bologna Process in Italy", in H. Schomburg and U. Teichler (eds.), Employability and Mobility of Bachelor Graduates in Europe. Key Results of the Bologna Process, Rotterdam, Sense Publishers, pp. 143-170.

CIPOLLONE, P. e P. Sestito (2010), Il capitale umano, Bologna, Il Mulino.

COLLINS, R. (2011), "Credential Inflation and the Future of Universities", Italian Journal of Sociology of Education, (2), pp. 228-251.
DE FRANCESCO, C. e P. Trivellato (1978), La laurea e il posto, Bologna, Il Mulino.

FONDAZIONE G. AGNELLI (2012), I nuovi laureati. La riforma del $3+2$ alla prova del mercato del lavoro, Roma-Bari, Laterza.

GHIRARDINI, P. G. e M. Pellinghelli (2000), I non disoccupati. Laureati e diplomati nell'Italia della piena occupazione, Bologna, Il Mulino.

GRANOVETTER, M. (1974), Getting a Job. A Study of Contacts and Careers, Cambridge (MA), Harvard University Press.

ISCED (International Standard Classification of Education) (2012), International Standard Classification of Education ISCED 2011, Montreal, UNESCO Institute for Statistics.

ISTAT (Istituto Nazionale di Statistica) (1990), Indagine 1989 sugli sbocchi professionali dei laureati, Roma, Istituto Nazionale di Statistica.

ISTAT (Istituto Nazionale di Statistica) (2014), Rilevazione sulle forze lavoro, Roma, Istituto Nazionale di Statistica.

ISTAT (Istituto Nazionale di Statistica) (2016), I percorsi di studio e lavoro dei diplomati e dei laureati. Indagine 2015 su diplomati e laureati 2011 (Statistiche Report), Roma, Istituto Nazionale di Statistica.

KYVIK, S. (2004), "Structural Changes in Higher Education Systems in Western Europe", Higher Education in Europe, 29(3), pp. 393-409.

MAESTRIPIERI, L. e C. Ranci (2016), "Non è un paese per laureati. La sovra-qualificazione occupazionale dei lavoratori italiani", Stato e Mercato, 108(3), pp. 425-450.

MOSCATI, R. (1986), I "cicli brevi" nell'istruzione superiore, Milano, Franco Angeli.

MOSCATI, R. (2006), "Italy", in J.J.F. Forest and P.G. Altbach (eds.), International Handbook of Higher Education. Part two: Regions and Countries, Dordrecht, Springer, pp. 811-828.

MOSCATI, R. e E. Pugliese (1996), "Higher Education and the Labour Market in Italy: Continuities and Changes", in Brennan, J., M. Kogan and U. Teichler (eds.), Higher Education and Work, London, Jessica Kingsley Publishers, pp. 118-135.

MOSCATI, R. e M. Rostan (2000), "Higher Education and Graduate Employment in Italy", European Journal of Education, 35(2), pp. 201-209.

OECD (2013), OECD Science, Technology and Industry Scoreboard 2013, Paris, OECD Publishing.

OECD (2015a), OECD Science, Technology and Industry Scoreboard 2015: Innovation for growth and society, Paris, OECD Publishing.

OECD (2015b), Education at a Glance 2015: OECD Indicators, Paris, OECD Publishing.

REYNERI, E. (2005), Sociologia del mercato del lavoro. Vol. I, Il mercato del lavoro tra famiglia e welfare, Bologna, Il Mulino.

ROSENBAUM, J. E.; T. Kariya; R. Settersten and T. Mayer (1990), "Market and Network Theories of 
the Transition from School High School to Work: Their Application to Industrialized Societies", Annual Review of Sociology, 16, pp. 263-299.

ROSTAN, M. (2006), Laureati italiani ed europei a confronto. Istruzione superiore e lavoro alle soglie di un periodo di riforma, Milano, Edizioni Universitarie LED.

ROSTAN, M. (2008), "Istruzione superiore, laureati e mondo del lavoro", in R. Moscati and M. Vaira (orgs.), L'università di fronte al cambiamento. Realizzazioni, problemi, prospettive, Bologna, Il Mulino, pp. 143-172.

ROSTAN, M. (2011), La professione accademica in Italia. Aspetti, problemi e confronti nel contesto europeo, Milano, LED Edizioni.

SANTORO, M. e M. Pisati (1996), Dopo la laurea. Status, sfide e strategie, Bologna, Il Mulino.

SCHOMBURG, H. and U. Teichler (2006), Higher Education and Graduate Employment in Europe: Results of Graduates Surveys from 12 Countries, Dordrecht, Springer.

SCHOMBURG, H. (2011) "Employability and Mobility of Bachelor Graduates: The Findings of Graduate Surveys in Ten European Countries on the Assessment of the Impact of the Bologna Reform", in H. Schomburg and U. Teichler (eds.), Employability and Mobility of Bachelor Graduates in Europe. Key Results of the Bologna Process, Rotterdam, Sense Publishers, pp. 253-273.
TEICHLER, U. (ed.) (2007), Careers of University Graduates: Views and Experiences in Comparative Perspective, Dordrecht, Springer.

TEICHLER, U. (2011), "Bologna - Motor or Stumbling Block for the Mobility and Employability of Graduates?", in H. Schomburg and U. Teichler (eds.), Employability and Mobility of Bachelor Graduates in Europe. Key Results of the Bologna Process, Rotterdam, Sense Publishers, pp. 3-41.

TOMLINSON, M. (2012), "Graduate Employability: A Review of Conceptual and Empirical Themes", Higher Education Policy, 25(4), pp. 407-431.

TREELLLE (2008), L'istruzione tecnica. Un'opportunità per I giovani, una necessità per il paese, Genova, Tipografia Araldica.

TROMBETTI, L. and A. Stanchi (2006), Laurea e lavoro. Tra aspettative degli studenti ed esigenze del mondo del lavoro, Bologna, Il Mulino.

TROW, M. (1974), "Problems in the Transition from Elite to Mass Higher Education", Policies for Higher Education, Paris, OECD, pp. 51-101.

TROW, M. (2006), "Reflections on the Transition from Elite to Mass to Universal Access: Forms and Phases of Higher Education in Modern Societies since WWII", in J. J. Forest and Ph. G. Altbach (eds.), International Handbook of Higher Education, Dordrecht, Kluwer Academic Publishers, pp. 243-280.

VISCO, I. (2009), Investire in conoscenza. Per la crescita economica, Bologna, Il Mulino.

Recebido a 10/08/2017. Aceite para publicação a 21/11/2017.

Michele Rostan (michele.rostan@unipv.it). Università degli Studi di Pavia, Dipartimento di Scienze Politiche e Sociali, CIRSIS - Centre for Study and Research on Higher Education Systems. Strada Nuova 65, 27100 Pavia, Italy. Adriana Stan (adrianastan03@gmail.com). Università degli Studi di Pavia, Dipartimento di Scienze Politiche e Sociali, CIRSIS - Centre for Study and Research on Higher Education Systems. Strada Nuova 65, 27100 Pavia, Italy. 